TITLE

\title{
USE OF COTTON GIN TRASH TO ENHANCE DENITRIFICATION IN RESTORED FORESTED WETLANDS
}

\section{Paper type: Research Paper}

\section{Authors:}

Sami Ullah $^{\mathrm{a}}$ and Stephen P. Faulkner

a. Louisiana State University, Wetland Biogeochemistry Institute, Baton Rouge, Louisiana 70803, USA.

b. USGS National Wetlands Research Center, 700 Cajundome Blvd., Lafayette, LA 70506, USA.

* Author for correspondence: Global Environmental and Climate Change Center, Department of Geography, McGill University, 610 Burnside Hall, 805 Sherbrooke St. West. Montreal, Quebec H3A 2K6, Canada

Email: sami.ullah@mcgill.ca phone: +1-514-398-4957, Fax: +1-514-398-7437

Key words: Bottomland hardwood forests; cotton gin trash; denitrification; Lower Mississippi Alluvial valley; $\mathrm{N}_{2} \mathrm{O}: \mathrm{N}_{2}$ emission ratio; water quality; wetland restoration

Abbreviations: CGT: Cotton gin trash, LMV: Lower Mississippi Alluvial Valley 
9 characteristic ecological functions including denitrifier activity. One way to enhance

10 denitrifier activity in restored wetland forests is to amend the soils with an available

11 carbon (C) source. This research investigated the effects of cotton gin trash (CGT)

12 amendment on denitrification rate and $\mathrm{N}_{2} \mathrm{O}: \mathrm{N}_{2}$ emission ratio from a restored bottomland

13 forest soils and compared it to those from an adjacent unamended natural forest soils.

14 CGT amendment increased denitrification rates in the restored forest soils to the level of 15 the natural forest soils. $\mathrm{N}_{2} \mathrm{O}: \mathrm{N}_{2}$ emission ratios from the restored and natural forest soils 16 were highly variable and were not significantly different from each other. These findings 17 suggest that restoration of bottomland hardwood forests in the LMV will require organic 18 carbon amendment to achieve enhanced denitrifier activity for $\mathrm{NO}_{3}$ removal while the 19 restored forest is developing into a mature state over time. 


\section{Introduction}

2

3 There is growing global concern about the increasing mineral nitrogen $(\mathrm{N})$ levels

4 in the environment and its subsequent impacts on aquatic ecosystems (Howarth et al.

5 2002; Galloway et al. 2002). Increasing discharge of reactive $\mathrm{N}$ from terrestrial

6 landscapes to estuaries and coastal ecosystems results in algal blooms and high primary

7 productivity, which leads to oxygen depletion and anoxia (Thompson et al. 2000). Run-

8 off from cultivated lands is the major cause of increased reactive $\mathrm{N}$ in rivers and lakes,

9 which affect more than $50 \%$ of surface water in the southeastern US (Neary et al. 1989).

10 Intensive agricultural practices in the Mississippi River basin have resulted in an increase

11 of $\mathrm{NO}_{3}$ concentration in the Mississippi River (Mitsch et al. 2005). Up to $70 \%$ of the

12 current total $\mathrm{NO}_{3}$ load of the Mississippi River has been attributed to agricultural runoff

13 (Goolsby 2000; Turner and Rabalais 2003). Widespread eutrophication and hypoxia in

14 the northern Gulf of Mexico has been linked to the increased $\mathrm{NO}_{3}$ and sediment loading

15 of the Mississippi River (Mitsch et al. 2001).

16 The Lower Mississippi Alluvial Valley (LMV) has lost more than $80 \%$ of its

17 native bottomland hardwood forests mainly from its conversion to agriculture

18 (MacDonald et al. 1979). This large-scale alteration has changed these landscapes from a

19 net $\mathrm{NO}_{3}$ sink to a net $\mathrm{NO}_{3}$ source. Natural forested wetlands have a tightly coupled $\mathrm{N}$

20 cycle and additional $\mathrm{NO}_{3}$ input from agricultural run-off into these ecosystems is either

21 used by vegetation, denitrified by heterotrophic microbes, or immobilized by bacterial

22 cells (Silvan et al. 2003: Ullah et al. 2005). Compared to upland forests, forested

23 wetlands are recognized for their high denitrification rates, which are a function of their

24 anaerobic soil conditions, high denitrifier populations, and readily available organic 
1 carbon (C) substrates (Lowrance et al. 1984; Delaune et al. 1996; Ingrid-Brettar and

2 Hofle 2002; Ullah et al. 2005).

3 Restoration of formerly forested wetlands as a method to improve water quality

4 in watersheds dominated by agriculture has received increased attention. Among others,

5 one goal of wetland restoration in agricultural watersheds is to enhance denitrification

6 capacity of the restored wetland for $\mathrm{NO}_{3}$ removal (Lowrance et al. 1984; Hunter and

7 Faulkner 2001; Mitsch et al. 2001; Ullah and Faulkner 2006). However, forested wetland

8 restoration is a long-term endeavor as restored forests take decades to reach maturity and

9 fully develop characteristic ecological functions including biogeochemical (Niswander

10 and Mitsch 1995; Shear et al. 1996; Battaglia et al. 2002; Ruiz-Jaen and Aide 2005).

11 Organic $\mathrm{C}$ is a key substrate for important microbiological processes including

12 denitrification in soils (DeLaune et al. 1996) and newly restored wetland soils often have

13 lower soil C than natural wetland soils (Craft and Reader 1999; Hunter and Faulkner

14 2001). Hunter (2000) reported that denitrification potential in a 10-year old restored

15 forested wetland was limited by available $\mathrm{C}$ substrate. Addition of cotton gin trash (CGT)

16 to soils collected from a 10-year old restored forest increased its denitrification rate by

$1745 \%$, suggesting that denitrification potential of restored forested wetlands can be

18 enhanced by amending soils with organic C such as CGT. CGT is produced at ginning

19 industries as flower residues while separating cotton fibbers from the rest of the

20 cotton flower. The southeastern states of the US (east of the Mississippi River)

21 produce about 500,000 to 700,000 tons of CGT from about 4.5 million acres of

22 cotton growing area annually (Rossi 2006). CGT is available at ginning industries 
1 free of cost and can be used as a $\mathbf{C}$ source for enhancing microbial activities in

2 restored wetlands in the region.

3 Organic $\mathrm{C}$ substrate in soils supports greater $\mathrm{N}_{2} \mathrm{O}$ reductase activity during

4 denitrification, leading to lower $\mathrm{N}_{2} \mathrm{O}$ emissions under low to moderate levels of soil $\mathrm{NO}_{3}$

5 (Sahrawat and Keeney 1986: Arah et al. 1990; Skiba et al. 1998). However, high $\mathrm{NO}_{3}$

6 loading into soils lead to higher $\mathrm{N}_{2} \mathrm{O}$ emissions (Bowden et al. 1991; Llyod 1995) raising

7 the issue of whether newly restored forested wetlands will increase the atmospheric

8 burden of $\mathrm{N}_{2} \mathrm{O}$ emissions when exposed to $\mathrm{NO}_{3}$ run-off from agricultural lands. Given the

9 significance of $\mathrm{N}_{2} \mathrm{O}$ as a potent greenhouse gas (IPCC 1996), it is important to account

10 for $\mathrm{N}_{2} \mathrm{O}$ emissions from all of its potential sources (Groffman et al. 2000b), including

11 newly restored forested wetlands.

12 We measured the effects of CGT amendment on denitrification rates and $\mathrm{N}_{2} \mathrm{O}: \mathrm{N}_{2}$

13 emission ratios from restored forested wetlands and compared it those from an adjacent

14 natural forested wetlands in the LMV. We hypothesized that amending restored forested

15 wetland soils with CGT would increase denitrification rates and reduce $\mathrm{N}_{2} \mathrm{O}: \mathrm{N}_{2}$ emission

16 ratio from the restored forested wetlands

17 Material and Methods

18 Description of the Research Sites

19 The research sites were located on the Panther Swamp National Wildlife Refuge

20 in the Yazoo delta region of Northwestern Mississippi (Figure 1). A 13-year-old restored

21 forested wetland ( 5 acres) and adjacent natural forested wetlands ( $\sim 10$ acres) were

22 selected for this study. We selected sites containing Sharkey clay soils (non-acidic

23 montmorilinitic, Vertic Haplaquept), because this soil series is common in the low- 
1 elevation areas of the LMV, covering about $12,150 \mathrm{~km}^{2}$. The natural forested wetland

2 was dominated by a mature stand of American elm (Ulmus americana), water oak

3 (Quercus nigra.), laurel oak (Q. laurifolia), red maple (Acer ruburum, L.), bitter pecan

4 (Carya $x$ lecontei), hackberry (Celtis leavigata) and dogwood (Cornus spp.). The soil

5 surface in the natural forest site was interspersed with dead logs and snags. The restored

6 site was dominated by young tree species of water oak (Quercus nigra), green ash

7 (Fraxinus pennsylvanica), honeylocust (Gleditsia triacanthos L.), dogwood (Cornus

8 spp.), and red maple ( Acer ruburum L.). This site was re-planted in 1990 after being

9 abandoned as an agricultural land.

10 Eight replicate sampling sites (pseudo-replicates) were randomly selected in both the

11 restored and natural forested wetlands. In the natural forested wetland, eight $1 \mathrm{~m}^{2}$ area

12 plots were marked at each sampling site. In the restored forested wetland, two plots each

13 of $1 \mathrm{~m}^{2}$ area were placed and marked at each sampling site. Two kilograms of CGT was

14 spread manually on the soil surface of one plot of the two plots of the restored

15 forested wetland, $\mathbf{1 5}$ days before the start of denitrification studies. The amendment

16 was left on the soil surface of the selected plots to avoid altering soil porosity and gas

17 flux. Cotton gin trash amendment represented $20 \mathrm{Mt} \mathrm{ha}^{-1}$ or about $1.5 \%$ of the total soil

18 dry weight in the upper $10 \mathrm{~cm}$. Cotton gin trash is $40 \%$ organic $\mathrm{C}$ and has a $\mathrm{C}: \mathrm{N}$ ratio of

19 18:1 (determined on CNS Finnigan analyzer), which can provide a readily mineralizable

20 organic $\mathrm{C}$ substrate to microbes in soils. The mean $\mathrm{NO}_{3}-\mathrm{N}$ and $\mathrm{NH}_{4}-\mathrm{N}$ contents of the

21 CGT were $15.4 \pm 3.6$ and $788 \pm 40 \mathrm{mg} \mathrm{kg}^{-1}$ cotton gin trash, respectively.

22 Denitrification, $\mathrm{N}_{2} \mathrm{O}: \mathbf{N}_{\mathbf{2}}$ Emission Ratio and $\mathrm{CO}_{2}$ Production Rates 
1 Duplicate intact soil cores $(5 \mathrm{~cm}$ dia. $\mathrm{x} 10 \mathrm{~cm}$ length) were collected from each plot

2 using a slide hammer (AMS-samplers, American Falls, Idaho) fitted with plastic liners (5

$3 \mathrm{~cm}$ dia. $\mathrm{x} 15 \mathrm{~cm}$ length) for the determination of denitrification rates, $\mathrm{N}_{2} \mathrm{O}: \mathrm{N}_{2}$ emission

4 ratios and $\mathrm{CO}_{2}$ production rates at 6-week intervals between October 2003 and April

52004 (5 times). Each core was amended with $3.3 \mathrm{~mL}$ of $1 \mathrm{~g} \mathrm{NO}_{3} \mathrm{~L}^{-1}$ solution to deliver 15

$6 \mu \mathrm{g} \mathrm{NO}_{3} \mathrm{~g}^{-1}$ dry soil to allow zero-order kinetics during denitrification with reference to

$7 \mathrm{NO}_{3}$ availability, and thus be able to assess CGT amendment effects. The soil core liners

8 were capped at the base and put back in the holes from which the cores were collected to

9 maintain field soil temperature conditions during incubation. To measure denitrification

10 rates, $10 \mathrm{ml}$ of purified $\mathrm{C}_{2} \mathrm{H}_{2}$ gas was injected in small aliquots into one of the duplicate

11 cores at the interface of soil and plastic liner to ensure diffusion of $\mathrm{C}_{2} \mathrm{H}_{2}$ throughout the

12 soil column (Ullah et al. 2005). After injection of $\mathrm{C}_{2} \mathrm{H}_{2}$ gas, the cores were capped and

13 fitted with a gas-tight rubber stopper for gas sampling. The final headspace of each core

14 after capping was $101 \mathrm{~cm}^{3}$. After capping, about $10 \mathrm{ml}$ additional $\mathrm{C}_{2} \mathrm{H}_{2}$ was replaced in

15 the headspace of $\mathrm{C}_{2} \mathrm{H}_{2}$ injected cores using a syringe. To measure net $\mathrm{N}_{2} \mathrm{O}$ emissions, the

16 other core was incubated without $\mathrm{C}_{2} \mathrm{H}_{2}$ addition.

17 Gas samples were collected from the headspaces of cores with a hypodermic needle

18 attached to a syringe at 0,30 and 60 minutes duration for $\mathrm{N}_{2} \mathrm{O}$ and $\mathrm{CO}_{2}$ concentration

19 determination. The samples were stored in 5-ml crimp-topped evacuated vials and

20 transferred to the laboratory for analysis within one week of collection on a Varian

21 CP38001 gas chromatorgraph (GC) equipped with an electron capture and flame

22 ionization detectors (ECD and FID). The GC was fitted with a methanizer, which reduced

$23 \mathrm{CO}_{2}$ in the samples to $\mathrm{CH}_{4}$ for detection by the FID. The rates of $\mathrm{N}_{2} \mathrm{O}$ and $\mathrm{CO}_{2}$ 
1 production were determined in $\mu \mathrm{g} \mathrm{N}_{2} \mathrm{O}-\mathrm{N} \mathrm{m}^{-2} \mathrm{~h}^{-1}$ and $\mathrm{mg} \mathrm{CO}_{2} \mathrm{~m}^{-2} \mathrm{~h}^{-1}$, respectively.

2 Corrections were made for dissolved $\mathrm{N}_{2} \mathrm{O}$ and $\mathrm{CO}_{2}$ by using the Bunsen's absorption

3 coefficients of 0.54 and 0.75 respectively. $\mathrm{N}_{2} \mathrm{O}: \mathrm{N}_{2}$ emission ratio was calculated from the

4 difference of $\mathrm{N}_{2} \mathrm{O}$ emitted from soil cores with and without $\mathrm{C}_{2} \mathrm{H}_{2}$ addition.

\section{$5 \quad$ Soil Sampling}

6 Bulk soil samples (0-10 $\mathrm{cm}$ deep) were collected from all 24 plots at six-week

7 intervals between October 2003 and April 2004 using a mud-auger. The soil samples

8 were transported on ice to the laboratory and refrigerated until use under their field-

9 moisture conditions. Intact soil cores (5 $\mathrm{cm}$ dia. $\mathrm{x} 10 \mathrm{~cm}$ length) were collected from each

10 plot using a slide hammer fitted with bronze liners for the determination of soil moisture,

11 bulk density, total porosity and percent water-filled pore spaces (WFPS).

\section{Soil Chemical Properties}

13 Field-moist soils (5 gram oven-dry soil weight equivalents) were weighed into

14 duplicate $250 \mathrm{ml}$ glass bottles and $50 \mathrm{ml}$ of 2 molar $\mathrm{KCl}$ solution was added to each

15 bottle. The bottles were shaken continuously for 1 hour on a reciprocating shaker,

16 centrifuged at a force of $50 \mathrm{Hertz} /$ minute for 5 minutes, and were then filtered into $20 \mathrm{ml}$

17 scintillation vials through a No.42 Whatman filter. The filtered samples were frozen until

18 analyzed for $\mathrm{NO}_{3}$ and $\mathrm{NH}_{4}$ with an automated Lachat flow injection analyzer. Average

$19 \mathrm{NO}_{3}$ and $\mathrm{NH}_{4}$ values for each soil sample were determined and reported in $\mathrm{mg} \mathrm{Kg}^{-1}$ oven-

20 dried soil. Soil $\mathrm{pH}$ was determined in the laboratory using 1:1 soil to de-ionized water

21 mixing ratio.

22 The bulk soil samples collected from each plot were oven dried, homogenized

23 thoroughly and pulverized. A subsample of about $35 \mathrm{mg}$ was weighed into a tin capsule 
1 prior to their injection into a Thermo Finnigan CNS analyzer for total soil C and N

2 contents at the USGS National Wetland Research Center, Lafayette, Louisiana. Total N

3 and organic $\mathrm{C}$ concentrations and bulk density measurements were used to calculate the

4 amounts of $\mathrm{N}$ and $\mathrm{C}$ present in the upper $10 \mathrm{~cm}$ on an area basis $\left(\mathrm{Mt} \mathrm{ha}^{-1}\right)$.

\section{$5 \quad$ Soil Physical Properties}

6 Intact soil cores (5 $\mathrm{cm}$ dia. $\mathrm{x} 10 \mathrm{~cm}$ length) were collected at each sampling date and

7 dried at $105{ }^{\circ} \mathrm{C}$ for 72 hours for the determination of soil moisture, bulk density and

8 porosity. These values were used to determine the percent water-filled pore spaces

9 (WFPS) for each core (Ullah et al. 2005) for the five sampling dates. Soil texture was

10 determined by the modified pipette method (Sheldrick and Wang 1993). Soil temperature

11 was measured with a soil temperature probe (inserted up to $10 \mathrm{~cm}$ depth) during the field

12 denitrification studies. Some of the soil physico-chemical characteristics of the selected

13 sites are given in Table 1.

\section{$14 \quad$ Statistical Analysis}

15 Differences in denitrification rates among the natural, CGT amended and

16 unamended restored forests were analyzed by two-way ANOVA analysis using the

17 general linear model. In the GLM model forest type and the 5 sampling dates were

18 treated as the categorical variables to assess the significance of differences among

19 denitrification rates of the restored and natural forested wetlands for each sampling date.

20 Significant differences in selected physico-chemical properties, $\mathrm{N}_{2} \mathrm{O}: \mathrm{N}_{2}$ emission ratio

21 and mineralizable organic carbon production rates among the forest types were analyzed

22 by one-way ANOVA. Fisher's protected LSD was used for comparison purposes at $\alpha=$

230.05 for all the ANOVA analysis. Pearson's correlation coefficients among denitrification 
1 rates, mineralizable organic $\mathrm{C}$, total soil $\mathrm{C}$ and $\mathrm{N}, \mathrm{NO}_{3}$ and $\mathrm{NH}_{4}$ concentrations were

2 determined. All statistical analyses were performed using SAS (SAS 1998). The proc

3 univariate procedure in SAS was applied to the data to check if the data met the normal

4 distribution and homogeneity of variance assumptions.

\section{$5 \quad$ Results}

Addition of CGT led to significant increases in denitrification rates in restored

7 forested wetland plots. In October, December, February, and March sampling,

8 denitrification rates in the CGT-amended plots were 5.7, 1.4, 2.6, and 1.3 times

9 greater than the unamended plots respectively, and were not significantly different

10 from the natural forested wetland soils (Figure 2). On average denitrification rates

11 were lower in February than in December despite high \%WFPS in all plots (93\%) (Table

12 2). Decrease in soil temperature from $8{ }^{\circ} \mathrm{C}$ in December to $5.8^{\circ} \mathrm{C}$ in February (Table 2)

13 may have decreased denitrifier activity. In March, soil temperatures rose to $14{ }^{\circ} \mathrm{C}$ (Table

14 2) and denitrification rates increased significantly in the CGT-amended, unamended and

15 natural forested wetland plots (Figure 3) compared to their rates in October, December,

16 February and April. After 6 months of CGT addition (April sampling) denitrification

17 rates of the CGT-amended plots remained higher than the unamended restored forest

18 plots (1.4 times higher), although statistically not significant. When compared within

19 each forest type, denitrification rates in the CGT-amended, unamended and natural

20 forested plots were highest in March and lowest in October. Higher denitrification rates

21 in March are attributed to higher \%WFPS and mineralizable organic $\mathrm{C}$ contents relative

22 to other sampling dates (Figure 2 and Tables 2 and 3). 
Denitrification rates in all the plots correlated significantly with mineralizable

2 organic $\mathrm{C}$ contents except in October and February sampling dates (Table 3). On average

3 mineralizable organic $\mathrm{C}$ of the natural and CGT amended restored forest plots were 2.3

4 and 1.5 times greater than those of the restored forest plots without CGT addition. An

5 exception occurred in October, shortly after the addition of CGT, when CGT amended

6 plots contained more mineralizable organic $\mathrm{C}$ than the natural forest plots. No significant

7 relationship between total soil $\mathrm{C}$ and $\mathrm{N}$ with denitrification rate was observed. Higher

8 denitrification rates observed in CGT amended plots resulted in 1.2 times lower soil $\mathrm{NO}_{3}$ -

$9 \mathrm{~N}$ concentration compared to the $\mathrm{NO}_{3}$ levels of the unamended plots (Table 1), even

10 though CGT amendment added an estimated $31 \mathrm{mg} \mathrm{NO}_{3}-\mathrm{N} \mathrm{m}^{-2}$ area initially. Soil $\mathrm{NO}_{3}-\mathrm{N}$

11 concentration of the natural forested wetland was also 1.3 times lower than those of the

12 unamended restored forested soil, although statistically non-significant (Table 1).

13 Amending restored forest soil with CGT lowered $\mathrm{N}_{2} \mathrm{O}: \mathrm{N}_{2}$ emission ratio by $33 \%$

14 compared to the unamended restored forest plots. However, due to the highly variable

$15 \mathrm{~N}_{2} \mathrm{O}: \mathrm{N}_{2}$ emission ratio those differences were statistically non-significant, except in

16 March (Figure 3). CGT amended and unamended restored forest plots had an average

$17 \mathrm{~N}_{2} \mathrm{O}: \mathrm{N}_{2}$ emission ratio of 0.40 and 0.53 , respectively, while natural forest plots had an

18 average emission ratio of 0.35 (across all sampling dates).

\section{Discussion}

20 Significant differences in a number of soil properties (Table 1) among the selected

21 forest types influenced denitrification rates. Lower bulk density, greater amount of total

22 soil $\mathrm{C}$, higher $\mathrm{C}: \mathrm{N}$ ratio (Table 1) and wetter soil conditions (Table 2) in the soils of the

23 natural forest ecosystem may have been the overriding factors supporting greater 
1 denitrifier activity than those observed in the unamended restored forest plots (Figure 2).

2 These findings indicate that restored forested wetland maintained significantly lower

3 denitrification rates than natural forested wetland, even though these measurements were

4 performed 13 years after restoration and both sites possessed similar soil type and

5 landscape position. Unlike vegetation structure and diversity which recover rapidly in

6 restored forests (Ruiz-Jean and Aide 2005), biogeochemical scale functions in restored

7 forested wetlands seem to be recovering at slower rates. Similar evidence is reported by

8 Ruiz-Jean and Aide (2005), who concluded that nutrient cycling, litter turnover and bulk

9 density in restored forests will take longer to recover to the level of mature forests.

10 Mineralizable organic $\mathrm{C}$ is an index of the amount of $\mathrm{C}$ substrate available to

11 denitrifiers (Blackmer et a. 1980; Singh-Bijay et al. 1988). The $42 \%$ higher

12 denitrification rates observed in the CGT amended plots compared to the unamended

13 restored forest plots (Figure 2) were due to the availability of higher amounts of

14 mineralizable organic $\mathrm{C}$ measured in the CGT amended plots (Table 3). These findings

15 suggest that addition of readily decomposable organic C substrate like CGT can enhance

16 denitrification rates in restored forested wetland soils to a level comparable to a more

17 mature forest system. This result is consistent with the findings of Hunter (2000), who

18 found $45 \%$ increase in denitrification rates in response to CGT amendment of soils

19 collected from similar ecosystems in the LMV. These observations support our

20 hypothesis that $\mathrm{CGT}$ addition enhances $\mathrm{NO}_{3}$ removal through denitrification by providing

21 a relatively higher and sustained organic $\mathrm{C}$ source to denitrifiers in restored forest soils in

22 the LMV. Mississippi, Louisiana and Arkansas lead the nation in the number of

23 acres restored under the wetland reserve program (WRP) of the US Department of 
1 Agriculture (USDA). By year 2001, about 346,994 acres were enrolled by private

2 landowners with USDA under the WRP program in the three states. These restored

3 acres provide ample opportunities for CGT re-use. Thus the practice of CGT

4 addition to restored wetland soils as a restoration technique to enhance denitrifier

5 activity in soils can also help recycle tons of CGT waste produced in the LMV,

6 besides water quality improvement.

7 In addition to forest age and organic $\mathrm{C}$ availability, WFPS also affected

8 denitrification rates in both the restored and natural forest soils. Denitrification rates

9 increased significantly with an increase in soil WFPS from an average $41 \%$ in October to

$1077 \%$ in December (Table 2). Similarly, denitrification rates were highest in March when

11 the soils were saturated and the rates lowered again in April most likely due to drying of

12 the soils as WFPS had declined to an average of 63\% by the time of April sampling. It

13 appears that lower soil temperature in February (Table 2) in spite of high WFPS resulted

14 in the observed decrease in denitrification rates in all the plots, which is in agreement

15 with the findings of Magg et al. (1997) who reported a decrease in denitrification

16 potential in riparian buffer soils with a decrease in soil temperature. Our findings clearly

17 show the importance of WFPS in regulating denitrifier activity in soils and are in

18 agreement with similar studies (Linn and Doran 1984; de Klein and van Logtestijn 1996;

19 Hefting et al. 2003; Ullah and Faulkner 2006). Given the importance of WFPS in

20 regulating denitrifier activity (Ullah et al. 2005; Ullah and Faulkner 2006), denitrification

21 rates in restored forested wetlands will depend on the extent of hydrologic modification

22 of the restored sites in addition to available organic $\mathrm{C}$ substrates. 
CGT-amended forest plots had relatively lower soil $\mathrm{NO}_{3}$ concentration than the

2 unamended plots. This observation support our finding that denitrifier activity in CGT

3 amended plots was sustained at higher rates, which resulted in lowering soil $\mathrm{NO}_{3}$ levels

4 compared to the unamended plots. $\mathrm{NO}_{3}$ immobilization by microbes in the CGT amended

5 and natural forest plots with higher $\mathrm{C}: \mathrm{N}$ ratios may have also contributed to lower soil

$6 \mathrm{NO}_{3}$ concentration in these plots compared to the uamended restored plots. Soils with

7 higher $\mathrm{C}: \mathrm{N}$ ratios have been reported to immobilize relatively more $\mathrm{NO}_{3}$ than soils with

8 lower C:N ratios (Silvan et al. 2003). At the observed rates of denitrification (averaged

9 over the study period), the amount of soil $\mathrm{NO}_{3}$ present per $\mathrm{m}^{2}$ (in the upper $10 \mathrm{~cm}$ of

10 soils) of natural, CGT-amended and unamended restored forests represent 29, 38 and 61

11 days supply in a year. Thus to maintain the observed denitrification rates and soil $\mathrm{NO}_{3}$

12 levels in these forests, $\mathrm{NO}_{3}$ must be continuously replenished either through nitrification

13 or run-off from agricultural lands and river diversions. Being N limited, forested wetlands

14 in the LMV can retain and reduce loss of external source $\mathrm{NO}_{3}$ through denitrification

15 besides plant uptake and microbial immobilization (Silvan et al. 2003). At the average

16 observed rates of denitrification, mature forested wetlands in the LMV can denitrify 28

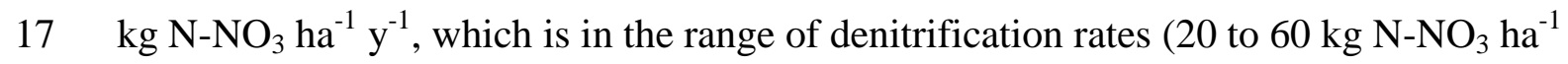

$\left.18 \mathrm{y}^{-1}\right)$ in riparian forests reported by Mitsch et al. (2001) and Ullah et al. (2005).

19 Although CGT amendment significantly increased denitrification rates, it resulted

20 in an averaged $33 \%$ lower $\mathrm{N}_{2} \mathrm{O}: \mathrm{N}_{2}$ emission ratio than those observed from the restored

21 site receiving no CGT (Figure 3). Being highly variable, the $\mathrm{N}_{2} \mathrm{O}: \mathrm{N}_{2}$ emission ratios from

22 the CGT and unamended restored forests sites were not significantly different from each

23 other. Similar high scatter in $\mathrm{N}_{2} \mathrm{O}$ relative to $\mathrm{N}_{2}$ emissions during denitrification from 
1 forest soils is encountered by other researchers (Tilsner et al. 2003; Groffman et al. 2000a

2 and 2000b). Higher scatter in the $\mathrm{N}_{2} \mathrm{O}: \mathrm{N}_{2}$ emission data does not support our hypothesis

3 that CGT addition significantly reduces net $\mathrm{N}_{2} \mathrm{O}$ emissions during denitrification in

4 forested wetlands. The effect of CGT on reducing $\mathrm{N}_{2} \mathrm{O}: \mathrm{N}_{2}$ emission ratio may have been

5 obscured by the additional $\mathrm{NO}_{3}$ added to soil columns before incubation as higher $\mathrm{NO}_{3}$

6 levels in soil leads to higher net $\mathrm{N}_{2} \mathrm{O}$ emissions (Llyod 1995). Since this research had

7 no experimental replicates for both the restored and natural forest sites, therefore,

8 temporally intensive (at daily cycle at least) $\mathrm{N}_{2} \mathrm{O}$ emission monitoring from multiple

9 restored and natural forested wetlands in the LMV is recommended to accurately

10 quantify the effects of organic $\mathrm{C}$ substrates and $\mathrm{NO}_{3}$ addition on net $\mathrm{N}_{2} \mathrm{O}$ emission

11 rates.

12 In summary, these results demonstrate that even after 13 years, the restored

13 forested wetland had not yet achieved the same denitrifying activity observed in the more

14 mature but otherwise similar naturally forested site. Addition of CGT to restored forested

15 wetlands in the LMV can enhance denitrification rates to the level of natural forested

16 wetlands provided denitrification is not limited by lower WFPS and soil temperature.

17 Restoration of forested wetlands in the LMV will require organic $\mathrm{C}$ amendments in order

18 to provide the same level of $\mathrm{NO}_{3}$ removal as natural forested wetlands before the restored

19 forest succeed into a mature state.

20 Acknowledgements

21 The authors acknowledge Dr. Kewei Yu, Louisiana State University Wetland

22 Biogeochemistry Institute, Mr. Michael Baldwin and Mr. Gregory Wolinsky, USGS

23 National Wetlands Research Center, Louisiana for their help during field sampling and 
1 laboratory analysis. We also thank USGS National Wetlands Research Center, Louisiana

2 and USDA National Sedimentation Laboratory, Mississippi for financially supporting

3 this project. 


\section{References}

Arah, R. R. M., and Smith, K. A. 1990. Factors influencing the fractions of gaseous products of soil denitrification evolved to the atmosphere as nitrous oxide. P 475-480. In A. F. Bouwman (eds.). Soils and Greenhouse Effect. John Wiley and Sons, New York.

Battaglia, L. L., Minchin, P. R., and Pritchett, D. W. 2002. Sixteen years of old-field succession and restablishment of a bottomland hardwood forest in the Lower Mississippi Alluvial Valley. Wetlands 22: 1-17.

Blackmer, A. M., Bremner, J. M., and Schmidt, E. L.1980. Production of nitrous oxide by ammonia-oxidizing chemiautotrophic microorganisms in soil. Appl. Environ.

Microbiol. 40:1060-1066.

Bowden, R. D., Melillo, J. M., Stedudler, P. A., and Aber, J. D. 1991. Effects of nitrogen additions on annual nitrous oxide fluxes from temperate forest soils in the Northeaster United States. J. Geophys.Res. 96: 9321-9328.

Craft, C., Reader, J. 1999. Twenty-five years of ecosystem development of constructed Spartina alterniflora (Loisel) marshes. Ecological Applications 9:1405-1419.

de Klein, C.A.M., and van Logtestijn, R. S. P. 1996. Denitrification in grassland soils in the Netherlands in relation to irrigation, $\mathrm{N}$-application rate, soil water content and soil temperature. Soil Bio.and Bioch. 28:231-237.

DeLaune R.D., Boar, R. R., Lindau, C. W., and Kleiss, B. A.1996. Denitrification in bottomland hardwood wetland soils of the Cache River. Wetlands 16: 309-320.

Galloway, J. N. and Cowling, E. B. 2002. Reactive nitrogen and the world: Two hundred years of change. Ambio 31: 64-71.

Goolsby D. A. 2000. Mississippi basin nitrogen flux believed to cause Gulf hypoxia. Trans.of the Am.Geophys. Union 81: 325-227.

Groffman, P. M, Gold, A. J., and Addy, K. 2000b. Nitrous oxide production in riparian zones and its importance to national emission inventories. Chemosphere-Global Change Science 2: 291-299.

Groffman, P. M., Brumme, R., Butterbach-Bahl, K., Dobbie, K. E., Mosier, A. R., Ojima, D., Papen, H., Parton, W. J., Smith, K. A., and Wagner-Riddle, C. 2000a Evaluating annual nitrous oxide fluxes at the ecosystem scale. Global Biogeochem. Cycles 14 (4): 1061-1070, GB001227.

Hefting, M. M., Bobbink, R., and de Caluwe, H. 2003. Nitrous oxide emissions and denitrification in chronically nitrated-loaded riparian buffer zones. J. Environ. Qual. 32:1194-1203. 
Howarth, R. W., Boyer, E. W., Pabich, W. J. and Galloway, J. N. 2002. Nitrogen use in the United States from 1961-2000 and potential future trends. Ambio 31:88-96.

Hunter, R.G. 2000. Comparison of biogeochemical functions between restored and natural bottomland hardwood wetlands. Ph.D. dissertation, Louisiana State University, Baton Rouge, Louisina.

Hunter, R.G. and Faulkner, S. P. 2001. Denitrification potential in restored and natural

Ingrid-Brettar, and Hofle, M. G. 2002. Close correlation between the nitrate elimination rate by denitrification and the organic matter content in hardwood forest soils of the upper Rhine floodplain (France). Wetlands Vol.21: 214-224.

Intergovernmental Panel on Climate Change. 1996. Climate change 1995: The science of climate change. Cambridge University press, Cambridge, UK.

Linn, D.M., and Doran, J. W. 1984. Effect of water-filled pore space on carbon dioxide and nitrous oxide production in tilled and non-tilled soils, Soil Sci. Soc. Am.J. 48:12671272.

Lloyd, D. 1995. Microbial processes and the cycling of atmospheric trace gases. Tends in Eco.and Evol. 10: 476-478.

Lowrance, R., Todd, R., Fail, J. Jr., Hendrickson, O. Jr., Leonard, R., and Asmussen, L. 1984. Riparian forests as nutrient filters in agricultural watershed. BioScience 34:374377.

MacDonald, P.O., Frayer, W.E., and Clauser, J. K. 1979. Documentation, chronology and future projections of bottomland hardwood habitat losses in the lower Mississippi alluvial plain: USFWS report, 427 p. Washington D.C.

Mitsch, W.J, Day, J. W. Jr., Gilliam, J. W., Groffman, P. M., and Hey, D. L. 2001. Reducing nitrogen loading to the Gulf of Mexico from the Mississippi River basin: Strategies to counter a persistent ecological problem. BioScience 373.

Neary, D. G., Swank, W. T., and Reikerk, H. 1989. An overview of non-point source pollution in the Southern United States. P. 1-7. In Proc. Of the symp.: Forested Wetlands of the Southern US, Orlando, FL. 12-14 July 1988. USDA Forest Service General Tech. Rep. SE-50. USDA, Ashville, NC.

Niswander, S.F. and Mitsch, W. J. 1995. Functional analysis of a two-year-old created instream wetland: hydrology, phosphorus retention, and vegetation survival and growth. Wetlands 15:212-225. 
Rossi, J. 2006. Using cotton byproducts in beef cattle diets. Bulletin No. 1311,

2 Cooperative Extension, College of Agricultural and Environmental Sciences, and Family

3 and Consumer Sciences, University of Georgia, USA.

4

Ruiz-Jean, M. C, and Aide, T. M. 2005. Vegetation structure, species diversity, and ecosystem processes as measures of restoration success. Forest Ecol. and Mange.218: 159-173.

Sahrawat, K. L., and Keeney, D. R. 1986. Nitrous oxide emission from soils. Adv. Soil. Sci. 4: 103-148.

SAS Institute. 1998. SAS User's Manual. SAS Inc. Carry, North Carolina, USA.

Shear, T. H., Lent, T. J., and Frayer, S. 1996. Comparison of restored and mature bottomland hardwood forests of southwestern Kentucky. Restoration Ecology 4: 111123.

Sheldrick B. H. and Wang, C. 1993. Particle size distribution. In Soil Sampling and Analysis, Edited by M.R. Carter, Canadian Soc. of Soil Sci. Lewis Publishers, Canada.

Silvan, N., Vasander, H., Karsisto, M., and Laine, J. 2003. Microbial immobilization of added nitrogen and phosphorus in constructed wetlands. Applied Soil Ecology 24: 143149

Singh-Bijay, Ryden, J. C., and Whitehead, D. C. 1988. Some relationships between denitrification potential and fractions of organic carbon in air-dried and field moist soils. Soil Bio.and Bioch. 20: 737-741.

Skiba, U. M., Sheppard, L. J., MacDonald, J., and Fowler, D. 1998. Some key environmental variables controlling nitrous oxide emissions from agricultural and seminatural soils in the Scotland. Atmos.Environ. 32: 3311-3320.

Thompson, S. P., Michael, M. F. and Paerl, H. W. 2000. Denitrification in an estuarine headwater creek within an agricultural watershed. J. Environ. Qual. 29:1914-1923.

Tilsner J., Wrage, N., Lauf, J., and Gebauer, G. 2003. Emission of gaseous nitrogen oxides from extensively managed grassland in NE Bavaria, Germany. 1. Annual budget of $\mathrm{N}_{2} \mathrm{O}$ and NOx emissions. Biogeochemistry 63: 229-247.

Turner, R. E and Rabalais, N. N. 2003. Linking landscape and water quality in the Mississippi River basin for 200 years. BioScience 53:563-572.

Ullah, S., Breitenbeck, G. A., and Faulkner, S. P. 2005. Denitrification and $\mathrm{N}_{2} \mathrm{O}$ emission from cultivated and forested alluvial clay soils. Biogeochemistry 73: 499-513. 
1 Ullah, S., and Faulkner, S. P. 2006. Denitrification potential of different landuse types in 2 an agricultural watershed, Lower Mississippi valley. Ecological Engineering (in press). 


\section{List of Figures:}

3 Figure 1. Location map of the Panther Swamp National Wildlife Refuge

4

5 Figure 2. Denitrification rates of natural, CGT amended and unamended restored forested 6 wetland soils in Panther Swamp National Wildlife Refuge, Mississippi. Similar small7 scale letters on top of each bar shows no significant difference in emission ratio among 8 the three forest types within each sampling date $(\mathrm{p}>0.05)$. Error bars are standard error 9 of the means.

10

11 Figure 3. Mean $\mathrm{N}_{2} \mathrm{O}: \mathrm{N}_{2}$ emission ratio of natural, CGT-amended and unamended restored 12 forested wetlands in Panther Swamp National Wildlife refuge, Mississippi. Similar 13 small-case letters on top of each bar shows no significant difference in emission ratio 14 among the three forest types within each sampling date ( $p>0.05)$. Error bars are standard 15 error of the means. 
1 Table 1. Physio-chemical properties of soil (0-10 $\mathrm{cm}$ depth) with standard errors from

2 restored and natural forested wetland sites samples collected in October 2003.

\begin{tabular}{llll}
\hline Variables & Natural & Restored + CGT & Restored \\
\hline Texture Class & Clay & Clay & Clay \\
\% Clay & $63(1.1) \mathrm{a} \dagger$ & $62(2.9) \mathrm{a}$ & $60(1.9) \mathrm{a}$ \\
$\%$ Silt & $22(1.6) \mathrm{a}$ & $24(3.5) \mathrm{a}$ & $25(1.3) \mathrm{a}$ \\
Bulk Density $\left(\mathrm{g} \mathrm{cm}^{3}\right)$ & $0.85(0.03) \mathrm{a}$ & $0.93(0.02) \mathrm{b}$ & $0.93(0.02) \mathrm{b}$ \\
Porosity $\left(\mathrm{cm}^{3} \mathrm{~cm}^{-3}\right)$ & $0.68 \mathrm{a}$ & $0.65 \mathrm{a}$ & $0.65 \mathrm{a}$ \\
pH & 4.7 & 5.6 & 5.5 \\
$\mathrm{NO}_{3}-\mathrm{N} \mathrm{mg} \mathrm{Kg}$ & $3.4(0.7) \mathrm{a}$ \\
$\mathrm{NH}_{4}-\mathrm{N} \mathrm{mg} \mathrm{Kg}{ }^{-1}(5$ months average $)$ & $7.2(1.3) \mathrm{a}$ & $4.9(1.0) \mathrm{ab}$ & $3.7(1.0) \mathrm{b}$ \\
Total soil C $(\%)$ & $3.5(0.2) \mathrm{a} * *$ & $3.1(0.1) \mathrm{ab}$ & $2.7(0.1) \mathrm{b}$ \\
Total soil N $(\%)$ & $0.22(0.01) \mathrm{a}$ & $0.22(0.01) \mathrm{a}$ & $0.22(0.01) \mathrm{a}$ \\
$\mathrm{C}: \mathrm{N}$ & 15 & 14 & 12.3
\end{tabular}

\footnotetext{
$3{ }^{\S}$ CGT: Cotton gin trash

$4 \uparrow$ Means followed by different letters shows significant difference at $\mathrm{p}<0.05$ and $* * \mathrm{p}<0.10$ between

5 forest types for different soil properties (ANOVA).
} 


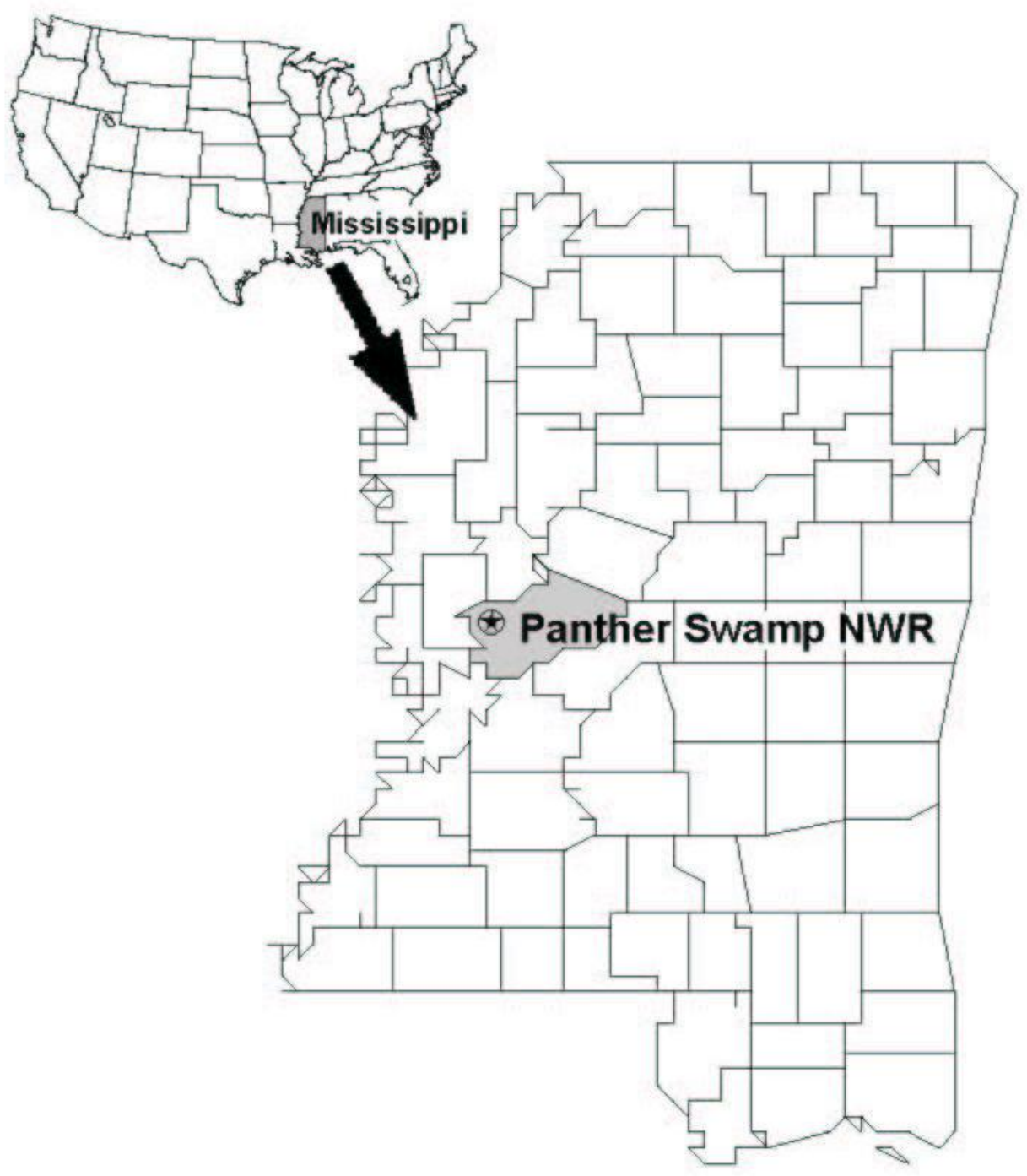

1

2 Figure 1. Location map of the Panther Swamp National Wildlife Refuge 3 


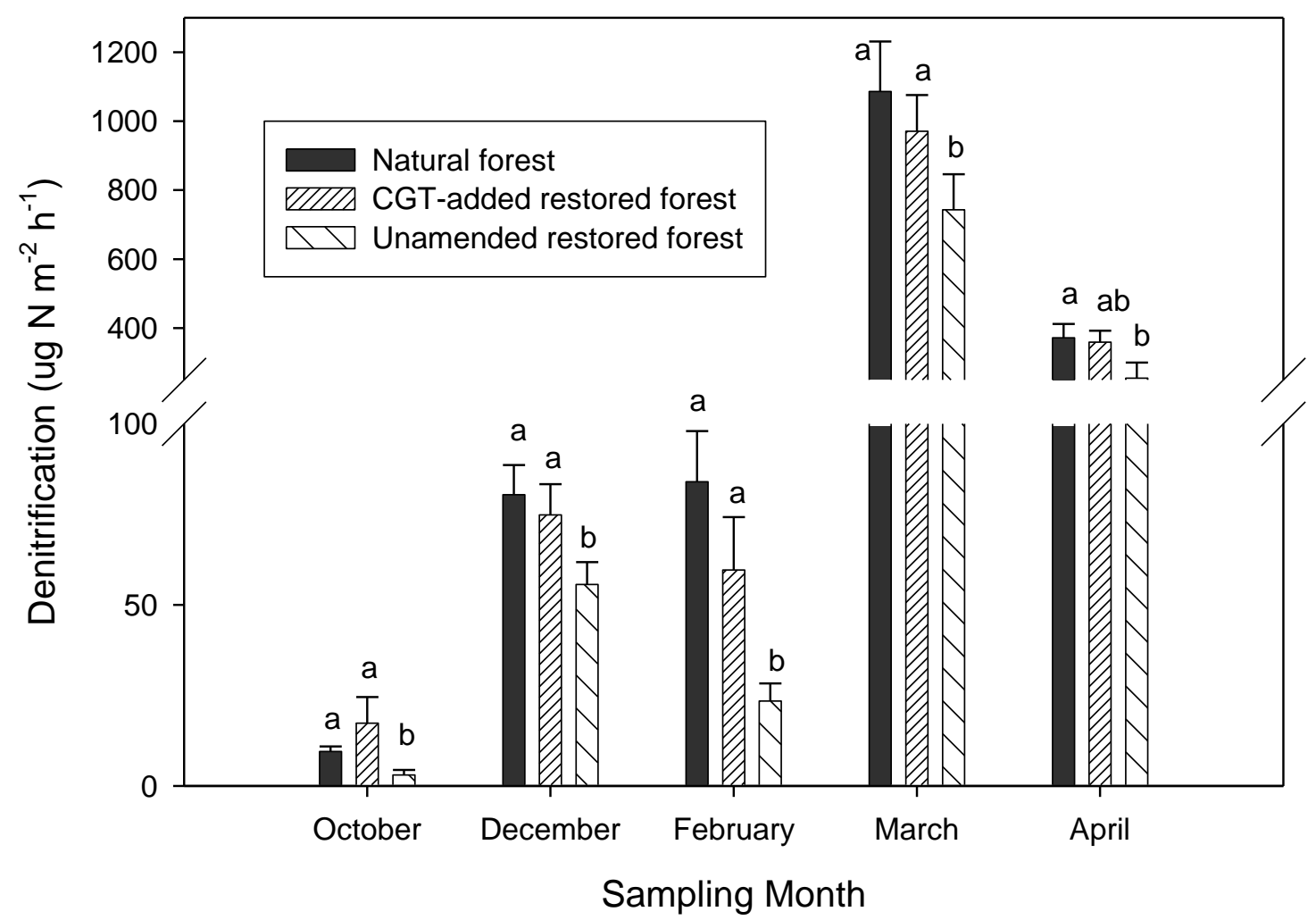

12 Figure 2. Denitrification rates of natural, CGT amended and unamended restored forested 3 wetland soils in Panther Swamp National Wildlife Refuge, Mississippi. Similar small4 scale letters on top of each bar shows no significant difference in emission ratio among 5 the three forest types within each sampling date $(p>0.05)$. Error bars are standard error 6 of the means. 
1 Table 2. Percent water-filled pore space and soil temperature $(0-10 \mathrm{~cm})$ of restored and 2 natural forest soils determined during denitrification studies. Each value in the table is an 3 average of 8 data points. Values in brackets are standard error of the means.

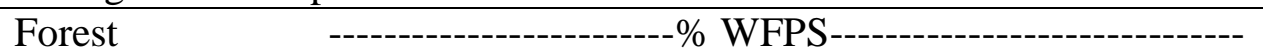

Type

\begin{tabular}{llllll} 
& October & December & February & March & April 2004 \\
& 2003 & 2003 & 2004 & 2004 & \\
\hline Natural & $37(0.01)$ & $71(0.03)$ & $92(0.04)$ & $100(0.03)$ & $70(0.02)$
\end{tabular}

Forest

Restored $\quad 44(0.02) \quad 82(0.01) \quad 94(0.02) \quad 88(0.02) \quad 56(0.02)$

Forest

$\begin{array}{llllll}\text { Soil Temp } & 19 & 8 & 5.8 & 14 & 19\end{array}$ $\left({ }^{\circ} \mathrm{C}\right)$

4 


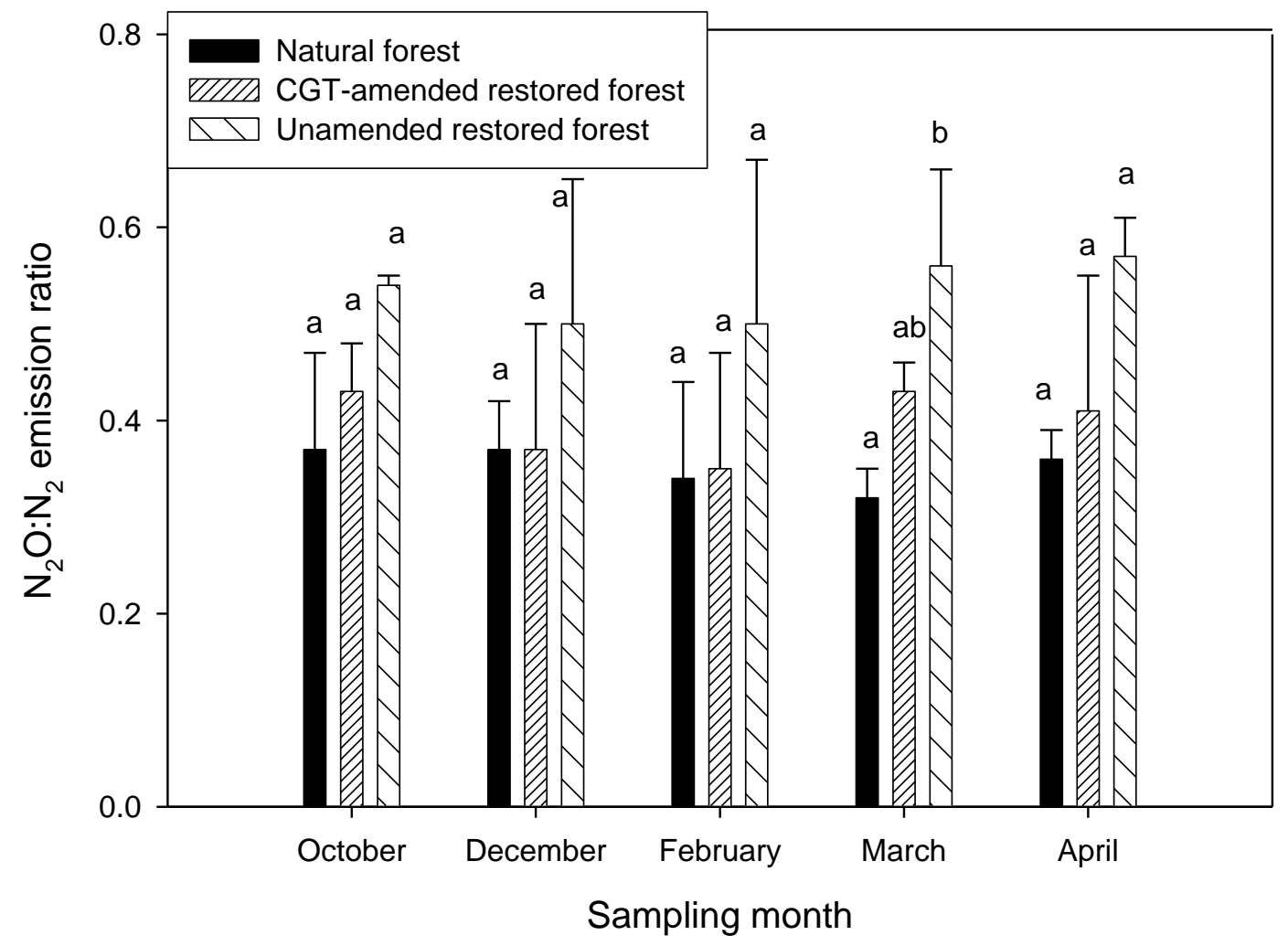

3 Figure 3. Mean $\mathrm{N}_{2} \mathrm{O}: \mathrm{N}_{2}$ emission ratio of natural, CGT-amended and unamended restored 4 forested wetlands in Panther Swamp National Wildlife Refuge, Mississippi. Similar

5 small-case letters on top of each bar shows no significant difference in emission ratio 6 among the three forest types within each sampling date ( $p>0.05)$. Error bars are standard 7 error of the means. 
2 Table 3. Organic carbon mineralization rate and its correlation with denitrification rates

3 of restored and natural forested wetland soils. Each value in the table is an average of 8

4 data points. Values in brackets are standard error of the means.

\begin{tabular}{cccc}
\hline $\begin{array}{c}\text { Sampling } \\
\text { times }\end{array}$ & Natural & Restored $+\quad$ Restored & \\
& & CGT & $\begin{array}{l}\text { Correlation of } \\
\text { Organic C with } \\
\text { denitrification }\end{array}$
\end{tabular}

$\begin{array}{lllll}\text { October } & 955(89) \mathrm{b}^{\dagger} & 1661(212) \mathrm{a} & 1267(196) \mathrm{ab} & 0.28 \mathrm{~ns} \\ \text { December } & 109(15) \mathrm{a} & 51(9) \mathrm{b} & 44(4) \mathrm{b} & 0.57^{*} \\ \text { February } & 37(1.4) \mathrm{a} & 13(3) \mathrm{b} & 10(2) \mathrm{b} & 0.22 \mathrm{~ns} \\ \text { March } & 249(56) \mathrm{ab} & 379(64) \mathrm{a} & 194(30) \mathrm{b} & 0.56^{*} \\ \text { April } & 326(26) \mathrm{a} & 307(18) \mathrm{a} & 194(29) \mathrm{b} & 0.70^{*}\end{array}$

$5 \quad{ }^{\dagger}$ Means followed by different letter indicate significant $(\mathrm{p}<0.05)$ difference between forest types within

6 each sampling time (ANOVA).

7 ns: non-significant, $*$ significant correlation at $\mathrm{p}<0.05$ and $\mathrm{n}=24$

10 